\title{
Hemşirelik Öğrencilerinin Stresle Başetme Düzeyleri İle Algıladıkları Sosyal Destek Arasındaki İliş ki
}

\section{Relationship between Coping Style with Stress and the Levels of Perceived Social Support among Nursing Students}

\author{
Hülya ÜSTÜNDAĞ $\breve{a}^{\mathrm{a}}$ Zeynep BOSTANCI ${ }^{\mathrm{b}}$ Birgül AYDOĞAN
}

ÖZ Amaç: Bu çalışma hemşirelik öğrencilerinin stresle baş etme düzeyleri ile algılanan sosyal destek arasındaki ilişkinin incelenmesi amacıyla yapıldı. Yöntem: Çalışmanın evrenini bir üniversitenin sağlık bilimleri fakültesinde lisans eğitimi gören hemşirelik öğrencileri oluşturdu. Herhangi bir örnekleme yöntemine başvurulmayıp çalışmaya katılmayı kabul eden bütün öğrenciler çalışma kapsamına alındı. Çalışmaya katılmayı kabul eden öğrencilere tanımlayıcı özellikleri içeren form, Stresle Başetme Tarzları Ölçeği ve Algılanan Sosyal Destek Ölçeği uygulandı. Verilerin değerlendirilmesinde yüzdelik, ortalama, Kruskall Wallis Varyans Analizi, Mann Whitney-U testleri ve Pearson korelasyon analizi kullanıldı. Bulgular: Öğrencilerin stresle baş etme tarzları ölçeği puanı $73.09 \pm 10.48$ olarak belirlendi. Ölçeğin alt boyutlarından puan ortalaması en yüksek KGY $20.39 \pm 4.33$, en düşük ÇY $16.53 \pm 5.20$

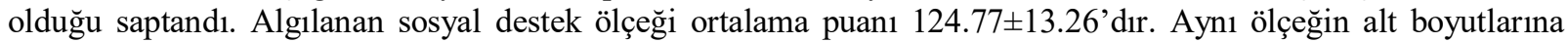

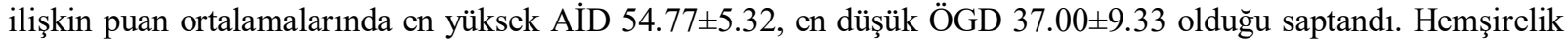
öğrencilerinin stresle başa çıkma düzeyleri ile algılanan sosyal destek düzeyleri arasındaki korelasyon analizinde aile ve arkadaş desteği düzeyi ile stresle başa çıkmada aktif/etkili tarz olan kendine güvenli yaklaşım (sırasıyla $\mathrm{r}=.194 \mathrm{p}<0.01 ; \mathrm{r}=.247 \mathrm{p}<0.01$ ), iyimser yaklaşım düzeyi arasında (sırasıyla $\mathrm{r}=.211 \mathrm{p}<0.01 ; \mathrm{r}=.248 \mathrm{p}<0.01$ ) pozitif yönde ve yüksek düzeyde ilişki belirlendi. Sonuç: Öğrencilerin öğrenim yaşamları süresince sosyal destek algılarının geliştirilmesinin, onların stresle baş etme tarzlarında aktif/etkili yolları kullanmasına katkı sağlayacağı düşünülmektedir.

Anahtar sözcükler: Algılanan sosyal destek, hemşirelik öğrencileri, stres, stresle baş etme tarzı

\begin{abstract}
Aim: The purpose of this study is to investigate the relationship between coping style with stress and the levels of perceived social support among nursing students. Methods: The study sample included 202 nursing students studying in the nursing department of a university's Faculty of Health Sciences. Any specific sampling method was not determined and only the voluntary students was enrolled in the study. Data for the study were collected using a personal information form, the Scale of Perceived Social Support, Stress-Coping Style Scale (SCSS). Percentage, arithmetic average and standard deviation, variance analysis, Kruskal Wallis, Mann Whitney U and Pearson correlation analysis are used in data evaluation. Results: This study confirmed that the students Stres Coping Style Scala average total score is $73.09 \pm 10.48$. According to the stres coping style scale, the highest average scores were generated in the subscale of self confident (20.39 \pm 4.33$)$ while the lowest average was found in the subscale of helpless styles $(16.53 \pm 5.20)$. Nursing students' perceived social support point average was found to be 124.77 \pm 13.26 . Subscale mean scores of the scale of perceived social support are as follows: Perceived support family (54.77 \pm 5.32$)$, perceived support teachers $(26.28 \pm 4.06)$ It was found that there was a positive and significant relationship between the level of family and friend support and the level of self-confident $(r=.194 \mathrm{p}<0.01 ; \mathrm{r}=.247$ $\mathrm{p}<0.01$ respectively), and optimistic approach $(\mathrm{r}=.211 \mathrm{p}<0.01 ; \mathrm{r}=.248 \mathrm{p}<0.01$ respectively). Conclusion: It is thought that the development of the social support perceptions of students during their education will contribute to the effective ways of coping with stress.
\end{abstract}

Key words: Stress, coping style with stress, perceived social support, nursing students.

Geliș Tarihi/Received:02-10-2018 Kabul Tarihi/Accepted:07-12-2018

a Dr. Öğr. Üyesi, İstanbul Bilgi Üniversiteli Sağlık Bilimleri Fakültesi, Hemşirelik Bölümü, e-posta: hulya.ustundag@ bilgi.edu.tr, ORCID: 0000-0001-6119-8573

bHemşire, İstanbul Bilgi Üniversitesi Sağlık Bilimleri Fakültesi, Hemşirelik Bölümü

'Hemşire, Şişli Hamidiye Etfal Eğitim Araştırma Hastanesi

Sorumlu yazar /Correspondence: Dr. Ögr. Üyesi Hülya Üstündağ, İstanbul Bilgi Üniversiteli, e-posta: hulya.ustundag@ bilgi.edu.tr,

Atıf: Üstündağ H, Bostancı Z, Aydoğan B. Hemşirelik öğrencilerinin stresle başetme düzeyleri ile algıladıkları sosyal destek arasındaki ilişki. Sağlık Bilimleri ve Meslekleri Dergisi 2019;6(1):74-83.

Citation: Üstündağ H, Bostancı Z, Aydoğan B. Relationship between coping style with stress and the levels of perceived social support among nursing students. Journal of Health Science and Profession 2019;6(1):74-83. 


\section{Giris}

Üniversite öğrenimi, öğrenciler açısından stresli bir dönemdir. $\mathrm{Bu}$ dönemde, yeni sosyal ilişkiler kurmak, ebeveynlerinden ve arkadaşlarından ayrılarak, yaşamlarını bağımsız bir şekilde sürdürmeye çalışmak, aşırı ders yükü, okuldaki akademik ortamın yoğun olması gibi faktörler ögrencilerde strese neden olan durumlardır. Stres, bireyin dengesini bozan çeşitli uyaranlara ya da çevresel etmenlere karşı gösterdiği genel tepkidir (1-3). Folkman ve Lazarus stresi, organizmanın bedensel ve ruhsal sinırlarının tehdit edilmesi ve zorlanması ile ortaya çıan bir durum olarak tanımlamışlardır. Stresle başa çıkma, kişiye özgü stres kaynaklarını değiştirme, tolere etme ya da kaçınma amacıyla, dış kaynaklı olumsuz olaylara karşı verilen tepkileri olumlu bir düzeyde tutabilme anlamına gelmektedir (2-4). Stres ve başa çıkma kuramı iki tür başa çıkmanın olduğunu farz etmektedir. Problem odaklı başa çıkma yaklaşımını kullanan kişiler, doğrudan stresli yaşantıyı değiştirmek için somut adımlar atma, problemle doğrudan meşgul olma, stresin kaynağına yönelik problemi direkt tanımlama, alternatifler hazırlama ve durumu değiştirmeye odaklı, aktif, mantıklı, serinkanlı, bilinçli çaba harcama eğilimindedir. Duygu odaklı başa çıkma; strese karşı olumsuz duyguları azaltma çabalarıdır. Duygu odaklı başa çıkma yaklaşımını kullanan kişiler için stres yaratıcı olan uyarıcı ile mücadele etmek yerine, bu uyarıcının etkisini azaltmaya yönelik durumun gerçekliğini yadsıma, sorundan uzak durma, kaçınma ve yaşadığı olumsuz duyguları sosyal çevresi ile paylaşma gibi etkinlikleri içerir (3-6).

Hemşirelik eğitiminin amac1; öğrenciye, hemşireliğin profesyonel özelliklerini öğretmek ve kazandırmak, kişisel gelişimini destekleyerek meslek yaşantısına en doğru şekilde hazırlamaktır. Hemşirelik eğitiminde de öğrencilerin kendilerini istendik bir şekilde ifade edebilmesi, stres verici durumlarla etkili baş edebilmesi, hayata ve geleceğe yönelik umutla bakabilmesi, plan yapabilmesi, kendi kararlarını verebilmesi ve pozitif tutumlara sahip olmaları beklenmektedir $(2,7,8)$. Öğrencilerin gerek eğitim alırken yaşadıkları akademik sorunlara, gerekse mesleğin gerektirdiği zorluklara uyum sağlayabilmeleri ve etkili baş edebilme yöntemlerinin geliştirilmesi önem kazanmaktadır.

Sosyal destek, bireyin kendisi ve yakın çevresi tarafindan oluşturulan sosyal ağın yeterince destekleyici olarak algılanması şeklinde tanımlanabilir. Sosyal ağ kişi ile çevresindeki diğer insanlar arasındaki bağları ve bu insanların birbirleriyle olan ilişkilerini anlatmak için kullanılan bir terimdir $(2,9,10)$. Sosyal destek, stres yaratan yaşam olaylarının algılanan önemini azaltarak ve sağlıklı davranışları kolaylaştırarak, bireyin duygusal gerginliklerinin üstesinden gelmesine yardım eder $(9,10)$.

Stresi önlemenin en etkin yollarından biri, yaşamın bütün alanlarında sosyal desteğe sahip olmaktır. Bireyin sosyal desteği almayı ve vermeyi öğrenmesi stres yaşantıları ile başa çıkmayı öğrenmesi açısından önemlidir $(2,4)$. Bulunulan herhangi bir çevrede, özveri temelinde kurulan arkadaşlıklar, geliştirilen insani ilişkiler ve bu amaçla yöneticilerce sunulacak hizmetler bireye önemli ölçüde sosyal destek sağlamaktadır. Sosyal destek, bireyin ihtiyaçlar hiyerarşisinde var olan ait olma, sevgi, takdir ve kendini gerçekleştirme gibi temel ihtiyaçlarının başka bireylerle (arkadaşları, ailesi, üstleri veya profesyonel danışmanlar vb.) kurduğu etkileşim sonucunda tatmin edilmesi anlamına gelmektedir. Yüksek düzeyde sosyal desteğe sahip olanların stres kaynaklarından biri olan güvensizlik hissine sahip olmamaları nedeniyle, aynı ortamda olmalarına rağmen sosyal desteğe sahip olmayan bireylere oranla daha az stres yaşadıkları araştırmalarla ortaya konulmuştur (2,4,9-11). Sosyal destek, stres vericileri ortadan kaldırmasa bile, kişilerin endişe düzeylerini düşürmekte, daha iyimser, kendilerini daha fazla kontrol edebilir, stresle başa çıkmak için yeni yollar deneme konusunda daha istekli olmalarını sağlamaktadır. Sosyal çevreden alınan yardımın içeriği ne olursa olsun kişilerin çaresizlik duygusunu azaltmakta ve stresle başa çıma konusunda kendine güveni arttırmaktadır $(9,12$ 15).

Toplumun sağlığ1 koruma ve geliştirme sorumluluğunu üstlenecek olan hemşirelik öğrencilerinin sosyal destek kaynaklarını etkili ve zamanında kullanmaları, onların kişisel ve mesleki uygulamalardan kaynaklanan stresörlerle etkili bir biçimde baş edebilmelerini yaşamlarındaki amaç ve düşüncelerini gerçekleştirme gücüne güvenme konusunda daha umutlu olabilmelerini, mesleki uygulamalarında da daha etkin ve kaliteli hizmet sunabilmelerinde önemli rol oynayabilir $(9,10,13$,15). $\mathrm{Bu}$ araştırma hemşirelik öğrencilerinin stresle 
başetme düzeylerinin algıladıkları sosyal destek arasındaki ilişkinin belirlenmesi amacıyla yapıldı ve aşağıdaki sorulara yanıt arandı.

- Hemşirelik öğrencilerinin stresle baş etme düzeyleri ve algıladıkları sosyal destek düzeyleri nedir?

- Hemşirelik öğrencilerinin stresle baş etme düzeyleri ve algıladıkları sosyal destek düzeyleri puanları demografik özelliklerine göre nasıl dağılım göstermektedir?

- Hemşirelik öğrencilerinin stresle baş etme düzeyleri ve algıladıkları sosyal destek arasındaki ilişki nasıldır?

\section{Gereç ve Yöntem}

\section{Araştırmanın Evren ve Örneklemi}

Tanımlayıcı türdeki araștırmanın evrenini İstanbul'da bir üniversitesinin Sağlık Bilimleri Fakültesi Hemşirelik bölümünde öğrenim gören 255 öğrenci oluşturdu. Örneklem ise, verilerin toplandığ gün okulda bulunan ve araştırmaya gönüllü olarak katılmayı kabul eden 202 öğrenciden oluştu.

\section{Veri Toplama Araçları}

Veriler, Sosyo-demografik Bilgi Formu, Stresle Başa Çıkma Tarzları Ölçeği (SBÇTÖ) ve Algılanan Sosyal Destek Ölçeği (ASDÖ) kullanılarak toplanmıştır. Sosyo-Demografik Bilgi Formu; Öğrencilerin yaş, cinsiyet, sınıf, nerede ve kimlerle yaşamakta oldukları, çalışma hayatları, anne ve babanın çalışma durumu, anne ve babanın aile içindeki tutumu, anne babanın hayatta olupolmadığını içeren sorulardan oluşmaktadır.

\section{Stresle Başa Çıkma Tarzları Ölçeği (SBÇTÖ),} Folkman ve Lazarus (1980) tarafindan geliştirilmiştir. Ölçek, kişinin stresli durumlarla karşılaştığında kullandığ 1 yöntemleri ve düşünceleri ölçmektedir. Türkçe geçerlik ve güvenirlik çalışması Şahin ve Durak (1995) tarafindan yapılmıştır. 30 maddeden oluşan ölçek, 4'lü likert tipinde olup her bir maddeden alınan puan 0-3 arasında değișmektedir. Kendine güvenli yaklaşım, iyimser yaklaşım, çaresiz yaklaşım, boyun eğici yaklaşım ve sosyal destek arama yaklaşımı olmak üzere beş alt ölçekten oluşmaktadır. Kendine güvenli yaklaşım, iyimser yaklaşım ve sosyal destek arama yaklaşımı problemi çözmeye yönelik olan aktif/etkili başa çıkma yollarıdır. Çaresiz yaklaşım ve boyun eğici yaklaşım duygulara yönelik olan pasif/etkisiz başa çıkma yollarıdır.
Ölçeğin toplam bir puanı yoktur. Her bir alt ölçek ortalama puanındaki artış, o baş etme yönteminin kişi tarafindan daha sik kullanıldığını göstermektedir. Ölçeğin 8., 10., 14., 16., 20., 23., 26. maddeleri K.G.Y.; 2, 4., 6., 12., 18. maddeleri İ.Y.; 3., 7., 13., 15., 21., 24. maddeleri Ç.Y.; 5., 7., 13., 15.,21., 24. maddeleri B.E.Y.; ve 1., 9., 29., 30. maddeleri ise S.D.A. maddeleridir (16).

Algılanan Sosyal Destek Ölçeği (ASDÖ), Y1ldırım (2004) tarafindan gerçekleştirilmiştir. Bireylerin ailesinden, arkadaş ve öğretmenlerinden elde ettiği sosyal destek düzeyini belirlemek amacryla geliştirilen ölçek, üç alt ölçek için ortak olan 50 durum cümlesinden oluşmaktadır. Yıldırım'a (2006) göre ASDÖ-R' de yer alan üç alt ölçek $\mathrm{AGD}=$ Aile desteği, $\mathrm{ARD}=$ arkadaş desteği, ÖGD=öğretmen desteği'ni ifade etmektedir (17). Ölçeğin aile desteği alt ölçeğinde 20, arkadaş desteği alt ölçeğinde 13, öğretmen desteği alt ölçeğinde 17 madde bulunmaktadır. Her alt ölçekte birer tane tersine çevrilmiş madde yer almaktadır. Ölçeğin her maddesinde yer alan ifade için bireylerin, "Bana uygun=3", "Bana kismen uygun=2" ve "Bana uygun değil=1" şeklinde seçeneklerle ölçek üzerinde işaretlemeleri beklenmektedir. Düz maddeler, oldukları gibi, tersine çevrilmiş maddeler ise tersinden hesaplanmalıdır. Ölçeklerin puan aralıkları şöyledir; Aile desteği, 20-60 puan; Arkadaş desteği, 13-39 puan; Öğretmen desteği, 17-51 puan; toplam ASDÖ 50-150 puandır. Ölçekten alınan yüksek puan, bireyin yüksek sosyal destek algıladığını, düşük puan ise bireyin düşük sosyal destek aldığı anlamına gelir (17).

\section{Araştırmanın Etik Yönü}

Çalışmanın yapılabilmesi için kurumdan yazılı izin ve kurumun bulunduğu üniversitenin etik kurulundan onay alındı. Çalışmaya katılan öğrencilere araştırma hakkında bilgi verildi, bireysel bilgilerin gizli kalacağı konusunda açıklama yapıldı. Araştırmaya katılan öğrencilerden yazılı onam alındıktan sonra, gönüllülük esası ilke edinilerek veriler topland.

\section{Verilerin Değerlendirilmesi}

Verilerin istatistiksel analizinde SPSS (Statistical Package for Social Science for Windows 23.0) paket programı kullanıldı. Tanımlayıcı istatistiksel analizlerinden sayı, yüzde, ortalama ve standart sapma ile hesapland. Verilerin dağılımı 
Kolmogorov Smirnov testi ile değerlendirildi. Gruplar arası karşılaştırmalarda Mann Whitney U test, Kruskal Wallis Test'inden yararlanıldı. $\mathrm{p}<0.05$ düzeyi istatistiksel olarak anlamlı kabul edildi.

\section{Bulgular}

Araştırmaya katılan öğrencilerin yaş ortalamaları $20.91 \pm 2.25$ 'dir. \%75.3'ü kadın, \%18.6'1 birinci sinıf, \% 22.8'i ikinci sınıf, \% 31.2'si üçüncü sınıf, \%21.4'ü dördüncü sınıf öğrencisidir. Çalışmaya katılan öğrencilerin \%93.6's1 bekar, \%84.2'si çalışmıyor, \%84.7'si yaşamını şehirde geçirmiş, \%61.6's1 evde ailesiyle yaşamakta, \%36.1'inin sadece babası çalışmaktadır. Öğrencilerin \% 84.7'sinin anne ve babası hayattadır ve \%76.9'u destekleyici ve koruyucu tutum sergileyen aileye sahiptir (Tablo 1).

Öğrencilerin stresle baş etme tarzları ölçeği puanı $73.09 \pm 10.48$ olarak belirlendi. Ölçeğin alt boyutlarından puan ortalaması en yüksek KGY $20.39 \pm 4.33$ en düşük CYY $16.53 \pm 5.20$ olduğu görüldü. Algilanan sosyal destek ölçeği ortalama puanı $124.77 \pm 13.26$ 'dır. Aynı ölçeğin alt boyutlarına ilişkin puan ortalamalarında en yüksek AİD 54.77 \pm 5.32 , en düşük ÖGD $37.00 \pm 9.33$ olduğu saptandı (Tablo 2). Çalışmada hemşirelik öğrencilerinin öğrenim gördükleri sınıf ile SBCÖ alt boyutlar1 olan $\mathrm{KGY}(\mathrm{p}=0.00), \dot{I} Y(\mathrm{p}=0.00), \mathrm{BEY}$ puanı $(p=0.04)$ arasında anlamlı fark olduğu, cinsiyet ile İY puanı arasında anlamlı fark olduğu ( $\mathrm{p}=0.00)$, anne baba tutumu ile KGY $(\mathrm{p}=0.00)$, SDA $(p=0.00)$ puanları arasinda anlamlı fark olduğu, anne babasının hayatta olması durumu ile IYY puanı $(\mathrm{p}=0.00)$ arasında anlamlı fark olduğu belirlendi (Tablo 3). Öğrencilerin anne baba tutumları ASDÖ alt boyutları olan AİD puanı ile arasında anlaml 1 fark olduğu $(\mathrm{p}=0.00)$ saptand 1 (Tablo3). Öğrencilerin sınıf, cinsiyet, yaşadığı yer, anne babanın çalışma durumu ve anne babanın hayatta olma durumu ile ASDÖ arasında anlamlı fark olmadığı belirlendi (Tablo 3).

Hemşirelik öğrencilerinin stresle başa çıka düzeyleri ile algilanan sosyal destek düzeyleri arasındaki ilişkiyi değerlendirmek üzere yapılan korelasyon analizi sonucunda aile ve arkadaş desteği artıkça stresle başa çıkmada aktif/etkili tarz olan kendine güvenli yaklaşım (sırasıyla $\mathrm{r}=.194$ $\mathrm{p}=0.00 ; \mathrm{r}=.247 \mathrm{p}=0.00$ ) ve iyimser yaklaşım düzeyi puanlarının arttığ 1 (sirasiyla $\mathrm{r}=.211 \mathrm{p}=0.00 ; \mathrm{r}=.248$ $\mathrm{p}=0.00$ ), öğretmen desteği puanı arttıkça iyimser yaklaşım düzeyi puanının arttığı görüldü (r=. $180 \mathrm{p}=0.01)$ (Tablo 4).

Tablo 1. Öğrencilerin Tanıtıcı Özellikleri (N=202)

\begin{tabular}{|c|c|c|c|}
\hline & & $\mathrm{n}$ & $\%$ \\
\hline Yaş Ort $\pm \mathrm{SS} 20$ & $91 \pm 2.25$ & & \\
\hline Sinıf & 1.Sinif & 40 & 18.6 \\
\hline & 2. Sinif & 49 & 22.8 \\
\hline & 3. Sinif & 67 & 31.2 \\
\hline & 4. Sinif & 46 & 21.4 \\
\hline Cinsiyet & Kadın & 162 & 75.3 \\
\hline & Erkek & 39 & 18.1 \\
\hline Medeni & Bekar & 189 & 87.9 \\
\hline Durum & Evli & 13 & 6.0 \\
\hline Kalınan yer & Ailesiyle evde & 133 & 61.6 \\
\hline & Arkadaşlarıyla evde & 33 & 15.3 \\
\hline & Yurt & 36 & 16.7 \\
\hline Anne & Otoriter & 20 & 9.3 \\
\hline babanın & Destekleyici & 166 & 76.9 \\
\hline tutumu & İlgisiz & 3 & 1.4 \\
\hline & Demokratik & 13 & 6.0 \\
\hline Anne baba & İkiside çalışıyor & 58 & 26.9 \\
\hline çalışma & İkiside çalışmıyor & 61 & 28.2 \\
\hline durumu & Sadece anne çalışıyor & 5 & 2.3 \\
\hline & Sadece baba çalışıyor & 78 & 36.1 \\
\hline Şimdiye & Şehir & 183 & 84.7 \\
\hline kadar & Kasaba & 16 & 7.4 \\
\hline yaşanılan yer & Köy & 3 & 1.4 \\
\hline Anne-Baba & İkisi yaşıyor & 183 & 84.7 \\
\hline durumu & Biri yaşıyor & 19 & 8.8 \\
\hline
\end{tabular}

\section{Tartıșma}

Öğrenciler, öğrenim yaşamları boyunca olumlu ya da olumsuz sonuçlanan birçok stresli olayla karş1laşırlar. Stresli olaylarla etkili mücadele edebilen öğrenciler; stres/zorluklara karşı fiziksel ve ruhsal sağlıklarını devam ettirebilirler. $\mathrm{Bu}$ öğrenciler, stresin olası zararlı etkilerinden korunmak için etkili baş etme stratejilerini kullanırlar ve stresli durumlarla mücadeleyi kendilerini geliştirebilecekleri firsatlara dönüştürebilirler. Hemşirelik öğrencilerinin stresle başa çıkma yöntemleri ile algılanan sosyal destek arasındaki ilişkinin belirlenmesi amacı ile yapılan bu çalışmada; öğrencilerin stresle başa çıkmada aktif tarzları daha fazla kullandıkları, bu tarzlar içerisinde en çok KGY yöntemini tercih ettikleri belirlendi. Şahin ve Buzlu'nun yaptığı çalışmada (7), Güler ve Çınar'ın yaptığı çalışmada (18), Ergin ve arkadaşlarının tıp fakültesi öğrencileri ile yaptığı 
Tablo 2. Stresle Başa Çıkma ve Algılanan Sosyal Destek Ölçeğinin alt boyut puan ortalamalarının dağılımı

\begin{tabular}{lllll} 
& & Ortalama & SD & Puan aralığ \\
\hline Stresle Başa & Kendine Güvenli Yaklaşım (KGY) & 20.39 & 4.33 & $7-28$ \\
Çıkma Tarzları & İyimser Yaklaşım (IY) & 13.23 & 3.15 & $5-20$ \\
Ölçeği & Çaresiz Yaklaşım (ÇY) & 16.53 & 5.20 & $8-32$ \\
& Boyun Eğici Yaklaşım (BEY) & 11.62 & 3.60 & $6-24$ \\
& Sosyal Destek Arama (SDA) & 11.24 & 2.16 & $4-16$ \\
& SBCÖ Toplam & 73.09 & 10.48 & $30-120$ \\
\hline \multirow{2}{*}{ Algılanan } & Aile Desteği (AİD) & 54.77 & 5.32 & $20-60$ \\
Sosyal & Arkadaş Desteği (ARD) & 35.14 & 3.77 & $13-39$ \\
Destek Ölçeği & Öğretmen Desteği (ÖGD) & 37.00 & 9.33 & $17-51$ \\
& ASDÖ Toplam & 124.77 & 13.26 & $50-150$ \\
\cline { 2 - 5 } & & &
\end{tabular}

çalışmada da (19) öğrencilerin en fazla KGY yöntemini kullandıkları ifade edilmiştir. Çalışma bu açıdan diğer çalışmaların sonuçları ile uyumludur. Al-Zayyat ve arkadaşlarının Suudi Arabistanda (20), Hamaideh ve arkadaşlarının Ürdün'de (21) farklı ölçekler kullanarak yaptığg çalışmalarında hemşirelik öğrencilerinin stresle baş etme yöntemi olarak problemi çözme, iyimser kalmayı kullandıklarını ifade ettiler $(20,21)$. Chan ve arkadaşlarının Hong Kong'ta hemşirelik öğrencileri ile yaptığ çalışmada stresle baş etmede, stresi farklı yöne transfer etmeyi (yemek yemek, uyumak gibi) ve iyimser kalmayı kullandıklarını belirttiler (22). Öğrencilerin stresle başa çıkmada pasif tarzlardan en az ÇY yöntemini kullandıkları belirlendi. Şahin ve Buzlu'nun yaptığı çalışmada (7), Temel ve arkadaşlarının yaptığ 1 çalışmada (23) öğrencilerin en az BEY yöntemini kullandıkları ifade edildi. Stresle başa çıkma tarzları ölçeğinden aldıkları toplam puan $(73.09 \pm 10.48)$ ve alt boyutlarından aldıkları puan ortalamanın üzerindedir. $\mathrm{Bu}$ çalışmada belirlenen puanlar Temel ve arkadaşlarının yaptığ 1 (23) ve Şahin ve Buzlu'nun yaptığı (7) çalışmadaki öğrencilerden elde edilen stresle başa çıkma tarzları ölçeğinin tüm alt gruplarından alınan puanlara göre daha yüksektir. Zhao ve arkadaşlarının (12) hemşirelik öğrencileri ile yaptığ algılarının orta düzeyde olduğunu ifade ettiler.

Ergin ve arkadaşlarının (19) yaptığı çalışmada ögrencilerin stresle baş etme yöntemleri puanları bu çalışmanın puanları ile benzerdir.
Çalışmada sınıf düzeyleri ile SBCÖ toplam puanı arasında anlamlı fark olmamasına karşın KGY, IYY, BEY alt grupları ile sinıf düzeyleri arasında istatistiksel olarak anlamlı fark bulundu. Birinci ve dördüncü siniflarda KGY, IYY stresle aktif/etkili baş etme yönteminin daha yüksek oranda kullanıldığı, ikinci ve üçüncü sınıflarda BEY olan pasif/etkisiz yaklaşımın daha yüksek olduğu görüldü. Çapık ve ark. hemşirelik öğrencileri ile yaptığ 1 çalışmada (8) dördüncü sınıfların KGY daha fazla kullandığı, üçüncü ve dördüncü sınıflarda iyimser yaklaşımın, boyun eğici yaklaşımın birinci sınıflardan yüksek olduğu belirlendi. Ekinci ve ark. yaptığı çalışmada (3), sınıf düzeyleri ve stresle başetme boyutları arasında anlamlı bir fark bulunmadığını ancak dördüncü sınıf öğrencilerinin diğer öğrencilere göre daha fazla, probleme yönelik çözüm yöntemlerini kullandıklarını ifade etmişlerdir. Güler ve Çınar'ın yapmış olduğu bir diğer çalışmada (18) son sınıf öğrencilerinin SDA puanlarının, üçüncü sınıfta eğitim gören öğrencilerin ise BEY puanlarının diğer sinıflara göre daha düşük olduğu saptanmıştır. Temel ve ark. yaptığı çalışmada (23) birinci sınıf ve dördüncü sınıf öğrencilerinin KGY puanlarının yüksek olduğu ikinci ve üçüncü sınıflarla aralarında anlamlı ilişki bulunduğunu belirttiler. Birinci ve dördüncü sinifların KGY puanlarının daha yüksek olması, birinci sınıfların büyük bir sınavı geçip üniversiteye başlamalarındaki güven, dördüncü sınıf öğrencilerinde ise mesleki yaşamlarına başlama aşamasına geldikleri ve eğitimlerini tamamlama 
Tablo 3. Demografik özellikler ile SBCÖ ve ASDÖ arasındaki ilişki

\begin{tabular}{|c|c|c|c|c|c|c|c|c|c|}
\hline & \multirow{2}{*}{ Özellikler } & \multicolumn{5}{|c|}{ Stresle Başçıkma Tarzları Ölçeği } & \multicolumn{3}{|c|}{ Algılanan Sosyal Destek Ölçeği } \\
\hline & & KGY & $\dot{\mathrm{I} Y}$ & $\mathrm{CY}$ & BEY & SDA & AID & ARD & ÖGD \\
\hline Sinıf & $\begin{array}{l}\text { 1.sinif } \\
2 . \text { sinıf } \\
\text { 3.sinıf } \\
\text { 4.sinif } \\
\text { p değeri }\end{array}$ & $\begin{array}{l}21.65 \pm 3.81 \\
19.12 \pm 3.77 \\
19.64 \pm 4.67 \\
21.76 \pm 4.21 \\
\mathbf{0 . 0 0}\end{array}$ & $\begin{array}{l}13.42 \pm 2.98 \\
12.22 \pm 3.15 \\
13.25 \pm 3.21 \\
14.10 \pm 3.02 \\
\mathbf{0 . 0 0}\end{array}$ & $\begin{array}{l}16.82 \pm 5.95 \\
16.28 \pm 5.22 \\
16.36 \pm 5.02 \\
16.78 \pm 4.88 \\
0.96\end{array}$ & $\begin{array}{l}10.67 \pm 3.85 \\
12.36 \pm 3.43 \\
12.08 \pm 3.89 \\
11.00 \pm 2.87 \\
\mathbf{0 . 0 4}\end{array}$ & $\begin{array}{l}11.72 \pm 1.81 \\
11.28 \pm 1.72 \\
10.83 \pm 2.39 \\
11.39 \pm 2.40 \\
0.25\end{array}$ & $\begin{array}{l}55.60 \pm 4.82 \\
53.95 \pm 6.20 \\
54.37 \pm 5.36 \\
55.50 \pm 4.56 \\
0.22\end{array}$ & $\begin{array}{l}35.27 \pm 4.15 \\
34.55 \pm 3.44 \\
34.91 \pm 3.77 \\
36.02 \pm 3.75 \\
0.05\end{array}$ & $\begin{array}{l}38.45 \pm 9.67 \\
36.77 \pm 8.92 \\
35.95 \pm 9.41 \\
37.52 \pm 9.44 \\
0.54\end{array}$ \\
\hline Cinsiyet & $\begin{array}{l}\text { kadın } \\
\text { erkek } \\
\text { p değeri }\end{array}$ & $\begin{array}{l}20.39 \pm 4.33 \\
20.33 \pm 4.45 \\
0.88\end{array}$ & $\begin{array}{l}12.95 \pm 3.22 \\
14.35 \pm 2.65 \\
\mathbf{0 . 0 0}\end{array}$ & $\begin{array}{l}16.70 \pm 5.10 \\
15.79 \pm 5.68 \\
0.19\end{array}$ & $\begin{array}{l}11.61 \pm 3.61 \\
11.76 \pm 3.62 \\
0.68\end{array}$ & $\begin{array}{l}11.24 \pm 2.17 \\
11.30 \pm 2.16 \\
0.93\end{array}$ & $\begin{array}{l}54.76 \pm 5.53 \\
54.79 \pm 4.45 \\
0.60\end{array}$ & $\begin{array}{l}35.16 \pm 3.90 \\
34.97 \pm 3.23 \\
0.42\end{array}$ & $\begin{array}{l}36.95 \pm 9.13 \\
36.92 \pm 10.1 \\
0.99\end{array}$ \\
\hline $\begin{array}{l}\text { Nerede } \\
\text { yaşadığı }\end{array}$ & $\begin{array}{l}\text { Ev(aile) } \\
\text { Ev(arkadaş/yalnız) } \\
\text { Yurt } \\
\text { p değeri }\end{array}$ & $\begin{array}{l}20.96 \pm 4.22 \\
19.54 \pm 4.08 \\
19.08 \pm 4.65 \\
0.05\end{array}$ & $\begin{array}{l}13.51 \pm 3.01 \\
13.18 \pm 3.49 \\
12.25 \pm 3.25 \\
0.09\end{array}$ & $\begin{array}{l}15.93 \pm 5.20 \\
18.28 \pm 5.57 \\
17.19 \pm 4.25 \\
0.09\end{array}$ & $\begin{array}{l}12.23 \pm 3.42 \\
12.78 \pm 4.32 \\
12.02 \pm 3.37 \\
0.11\end{array}$ & $\begin{array}{l}11.16 \pm 2.18 \\
11.63 \pm 2.17 \\
11.19 \pm 2.09 \\
0.58\end{array}$ & $\begin{array}{l}54.73 \pm 5.29 \\
54.84 \pm 5.14 \\
54.83 \pm 5.77 \\
0.84\end{array}$ & $\begin{array}{l}35.29 \pm 3.79 \\
34.93 \pm 3.68 \\
34.80 \pm 3.88 \\
0.59\end{array}$ & $\begin{array}{l}37.63 \pm 9.37 \\
33.66 \pm 9.51 \\
37.75 \pm 8.56 \\
0.07\end{array}$ \\
\hline $\begin{array}{l}\text { Anne-baba } \\
\text { tutumu }\end{array}$ & $\begin{array}{l}\text { Otoriter } \\
\text { Destekleyici/koruyucu } \\
\text { İlgisiz } \\
\text { Demokratik } \\
\text { p değeri }\end{array}$ & $\begin{array}{l}19.25 \pm 4.43 \\
20.89 \pm 4.13 \\
14.66 \pm 5.50 \\
16.84 \pm 4.09 \\
\mathbf{0 . 0 0}\end{array}$ & $\begin{array}{l}13.10 \pm 3.19 \\
13.37 \pm 3.14 \\
9.66 \pm 4.16 \\
12.46 \pm 2.78 \\
0.25\end{array}$ & $\begin{array}{l}18.45 \pm 5.14 \\
16.21 \pm 5.16 \\
15.33 \pm 6.65 \\
17.92 \pm 5.25 \\
0.29\end{array}$ & $\begin{array}{l}12.40 \pm 3.51 \\
11.53 \pm 3.64 \\
11.00 \pm 2.64 \\
11.76 \pm 3.67 \\
0.64\end{array}$ & $\begin{array}{l}11.85 \pm 1.95 \\
11.39 \pm 2.04 \\
7.33 \pm 1.52 \\
9.38 \pm 2.43 \\
\mathbf{0 . 0 0}\end{array}$ & $\begin{array}{l}51.10 \pm 7.36 \\
55.60 \pm 4.33 \\
43.00 \pm 3.60 \\
52.53 \pm 74 \\
\mathbf{0 . 0 0}\end{array}$ & $\begin{array}{l}35.10 \pm 5.26 \\
35.31 \pm 3.47 \\
32.66 \pm 1.52 \\
33.69 \pm 5.00 \\
0.14\end{array}$ & $\begin{array}{l}39.35 \pm 7.60 \\
36.69 \pm 9.50 \\
42.66 \pm 2.08 \\
36.07 \pm 10.24 \\
0.45\end{array}$ \\
\hline $\begin{array}{l}\text { Anne-baba } \\
\text { çalışma } \\
\text { durumu }\end{array}$ & $\begin{array}{l}\text { Her ikisi çalışıyor } \\
\text { Her ikisi çalışmıyor } \\
\text { Sadece anne çalışıyor } \\
\text { Sadece baba çalışıyor } \\
\text { p değeri }\end{array}$ & $\begin{array}{l}20.10 \pm 3.75 \\
19.77 \pm 4.36 \\
20.60 \pm 2.07 \\
21.08 \pm 4.76 \\
0.19\end{array}$ & $\begin{array}{l}13.46 \pm 2.57 \\
12.70 \pm 3.18 \\
11.80 \pm 1.64 \\
13.56 \pm 3.54 \\
0.11\end{array}$ & $\begin{array}{l}16.17 \pm 4.62 \\
15.98 \pm 5.71 \\
15.00 \pm 3.80 \\
17.33 \pm 5.25 \\
0.43\end{array}$ & $\begin{array}{l}11.62 \pm 3.60 \\
11.98 \pm 4.05 \\
10.20 \pm 1.64 \\
11.44 \pm 3.34 \\
0.80\end{array}$ & $\begin{array}{l}11.39 \pm 2.26 \\
11.40 \pm 2.03 \\
11.60 \pm 0.54 \\
10.98 \pm 2.24 \\
0.30\end{array}$ & $\begin{array}{l}54.62 \pm 5.98 \\
54.70 \pm 4.81 \\
54.80 \pm 2.77 \\
54.93 \pm 5.37 \\
0.80\end{array}$ & $\begin{array}{l}35.17 \pm 3.50 \\
34.80 \pm 3.50 \\
35.60 \pm 1.51 \\
35.37 \pm 4.28 \\
0.38\end{array}$ & $\begin{array}{l}35.77 \pm 8.75 \\
35.62 \pm 9.24 \\
36.40 \pm 10.87 \\
39.03 \pm 9.54 \\
0.11\end{array}$ \\
\hline $\begin{array}{l}\text { Anne-baba } \\
\text { hayatta olması }\end{array}$ & $\begin{array}{l}\text { Her ikisi de hayatta } \\
\text { Anne/baba hayatta } \\
\text { değil } \\
\text { p değeri }\end{array}$ & $\begin{array}{l}20.57 \pm 4.27 \\
18.68 \pm 4.64 \\
0.18\end{array}$ & $\begin{array}{l}13.44 \pm 3.10 \\
11.15 \pm 2.98 \\
0.00\end{array}$ & $\begin{array}{l}16.63 \pm 5.17 \\
15.57 \pm 5.53 \\
0.30\end{array}$ & $\begin{array}{l}11.63 \pm 3.66 \\
11.52 \pm 3.13 \\
0.94\end{array}$ & $\begin{array}{l}11.26 \pm 2.14 \\
11.10 \pm 2.37 \\
0.94\end{array}$ & $\begin{array}{l}54.99 \pm 5.19 \\
52.63 \pm 6.20 \\
0.10\end{array}$ & $\begin{array}{l}35.24 \pm 3.68 \\
34.21 \pm 4.58 \\
0.27\end{array}$ & $\begin{array}{l}37.09 \pm 9.42 \\
36.10 \pm 8.51 \\
0.69\end{array}$ \\
\hline
\end{tabular}


Tablo 4. SBCÖ ile ASDÖ arasındaki korelasyon

\begin{tabular}{lllllll}
\hline & AID & \multicolumn{3}{c}{ ARD } & \multicolumn{3}{l}{ ÖGD } \\
\hline & $\mathrm{r}^{*}$ & $\mathrm{p}$ & $\mathrm{r}$ & $\mathrm{p}$ & $\mathrm{r} *$ & $\mathrm{p}$ \\
\hline KGY & 0.194 & $\mathbf{0 . 0 0 6}$ & 0.247 & $\mathbf{0 . 0 0 0}$ & 0.094 & 0.182 \\
IY & 0.211 & $\mathbf{0 . 0 0 3}$ & 0.248 & $\mathbf{0 . 0 0 0}$ & 0.180 & $\mathbf{0 . 0 1 0}$ \\
CY & 0.055 & 0.435 & 0.091 & 0.199 & 0.017 & 0.813 \\
BEY & 0.053 & 0.450 & 0.018 & 0.801 & 0.122 & 0.085 \\
SDÖ & 0.007 & 0.924 & 0.081 & 0.254 & 0.130 & 0.066
\end{tabular}

*Pearson korelasyon testi

süreci içinde olmaları nedeniyle kendilerine daha fazla güven duymasından kaynaklandığ 1 düşünülebilir. Çalışmada öğrencilerin cinsiyet ile stresle başa çıkma alt grubu olan IYY arasında anlamlı fark olduğu belirlendi. Ekinci ve ark. yaptığı çalışmada (3) stresle başa çıkma ve kızerkek öğrenciler arasında anlamlı fark bulamadıklarını bildirdiler. Erkin ve arkadaşlarının çalışmasında erkek öğrencilerin KGY ve İY puanlarının anlamlı olarak daha yüksek olduğunu ifade etmișlerdir (19).

Çalışmada evde ailesiyle birlikte yaşayan ögrencilerin diğerlerine göre KGY ve İY puanlar1nın anlamlı olarak daha yüksek olduğu görüldü. $\mathrm{Bu}$ sonuç benzer çalışmalarla uyumludur $(3,8,18,23)$. Arkadaşları ile ailesinden ayrı olarak yaşayan öğrencilerin ÇY puanlarının anlamlı olarak yüksek olduğu saptandı. Üniversite öğrencisinin eğitimi boyunca kaldığı yer de stresle başa çıkmayı etkileyen değişkenlerden birisidir. Aile yanında olmak öğrencinin yaşamında birçok şeyi kolaylaştırdığı gibi, ailenin varlığının ve desteğinin daha fazla hissedilmesine neden olmaktadır. $\mathrm{Bu}$ durumun öğrencinin kendine güveninin ve iyimser yaklaşımının artmasını sağlamada önemli bir etken olduğu düşünülmektedir.

Anne babanın öğrenciye olan tutumu ile stresle baş etme karşılaştırıldığında, destekleyici/koruyucu aileye sahip olan öğrencilerin KGY puanlarının anlamlı olarak yüksek olduğu yine destekleyici/koruyucu ve otoriter aileye sahip olanların SDA puanlarının anlamlı olarak yüksek olduğu ve yapılan ileri analizde bu farkın ilgisiz aileye sahip olan öğrencilerle olduğu saptandı. KGY ve SDA aktif/etkili baş etme yöntemleridir. Ailesini yanında hisseden öğrencilerin karşılaştıkları stresli durumlarda aktif/etkili baş etme yöntemlerini kullandıkları görülmüştür. Bu durum literatürle uyumludur $(6,8,12)$. KGY yöntemini kullanan bireyler kendini rahatlıkla ifade edebilmekte ve problem durumlarında kaçmaktan çok yaklaşıp bilişsel, etkili ve davranışsal çözümler üretme çabasında olmaktadır. SDA ise, bir davranış olarak bireyin yakın çevresinden yardım istemesi ve verilen desteği kabul etmesini içerir. Literatürde sosyal desteğe sahip olmanın stres yaşantılarında istenmeyen etkilere karşı bireyi koruyucu bir etkisi olduğu kabul edilmektedir $(10,11,12,13$,).

Anne-babas1 hayatta olma durumu ile stresle baş etme karşılaştırıldığında, annesi-babası hayatta olan öğrencilerin IYY puanlarının yüksek olduğu ve istatistiksel olarak anlamlı fark olduğu belirlendi. Anne babanın varlığının hissedilmesi öğrencinin çevresine, olaylara daha iyimser yaklaşmasına için en önemli nedenlerden biri olduğu düşünülmektedir. Üniversite öğrencileri için en önemli sosyal destek kaynakları olarak onların ailesi ve arkadaşları olduğu bilinmektedir. Yeterli düzeyde sosyal destek alan öğrenciler, problemlerini çok büyük boyutlara varmadan çözmekte ve öğrenim yaşantısında daha büyük başarılar elde etmektedirler. Öğrencilerin ASD puan ortalamas1 $124.77 \pm 13.26$ olup, AID puan1 ortalamas1 $54.77 \pm 5.32$ ARD puan ortalamas1 $35.14 \pm 3.77 \mathrm{ve}$ ÖGD puanı ortalamas1 $37.00 \pm 9.33$ puandır. Ölçekten alınacak en yüksek puanın 150 olduğu göz önüne alınırsa katılımcıların algıladığ1 sosyal desteğin iyi düzeyde olduğunu söylemek mümkündür. Ölçeğin alt boyutları değerlendirildiğinde, aile, arkadaş ve ögretmenden algilanan sosyal destek düzeylerinin de yüksek olduğu söylenebilir. Bunların içinde aile desteğinin en yüksek puana, sahip olduğu belirlendi. Yapılan benzer çalışmalarda da öğrencilerin aile desteği 
algılarının daha yüksek olduğu, bu doğrultuda çalışmanın benzer çalışmalarla uyumlu olduğu bulundu (14)

Algilanan sosyal destek alt grupları ile sinıf düzeyleri ve cinsiyet arasinda anlamlı fark bulunmadığ 1 belirlendi $(p>0.05)$. Aydın ve arkadaşlarının yaptığı çalışmada (10), Tayfur ve Ulupınar'ın yaptığg çalışmada (14), Yılmazel'in yaptığı çalışmada (24) sınıf düzeyleri ve cinsiyet ile algilanan sosyal destek boyutları arasinda anlamlı fark olmadığı ifade edilmiştir. Çalışma sonuçları bu bulgularla uyumludur.

Öğrencilerin üniversiteye başladıktan sonra yurtta kalan ve ailesiyle birlikte evinde kalanların puanlarının, arkadaşlarıyla birlikte ya da yalnız evde kalanlardan daha yüksek öğretmen desteği algıladıkları ve istatistiksel açıdan anlamlı olduğu belirlendi. Yılmazel'in yaptığı çalışmada (24) yurtta kalan ögrencilerde arkadaş sosyal desteği puanları daha düşük, arkadaşlarıyla evde kalan öğrencilerde daha yüksek saptanmıştır ve gruplar arasındaki fark istatistiksel açıdan anlamlı bulunduğu belirtilmiştir. Ailesinden ayrılarak üniversiteye başlayan öğrencilerin arkadaşlarıyla aynı evi paylaşması ve bu paylaşımın sosyal destek puanlarına farklı çalışmalarda farklı etki etmesi, onların ailesinden uzakta iken alamadığ 1 sosyal desteği ve beklentilerini arkadaşlarından karşılayıp karşılayamama ile ilişkili olduğu düşünülmektedir. Tayfur ve Ulupınar çalışmasında da (14) kaldığı yerden memnun olan öğrencilerin algıladıkları sosyal destek alt boyutu puanlarının daha yüksek olduğunu ifade etmişlerdir.

Anne baba çalışma durumu ve anne babanın hayatta olma durumu ile algilanan sosyal destek alt boyutların arasında anlamlı bir fark olmamasına rağmen, anne babasının her ikisi de hayatta olan öğrencilerin algilanan sosyal destek alt boyutlarının puanı daha yüksek olduğu belirlendi. Öğrencilerin anne babasından algıladıkları sosyal destek onların zor zamanlarda çözüme ulaşabilmeleri açısından önem taşımaktadır. Hemşirelik öğrencilerinde aile ve arkadaş desteği ile kendine güvenli ve iyimser yaklaşım ve öğretmen desteği ile iyimser yaklaşım ile ilişkilidir. Aile desteği ve arkadaş desteği alan öğrencilerin kendine güvenli yaklaşımı ve iyimser yaklaşımı daha fazla kullandıkları, aile, arkadaş, öğretmen desteği algılayan öğrencilerin çekimser yaklaşım, boyun eğici yaklaşımı daha az kullandıkları saptanmıştır.

\section{Sonuç ve Öneriler}

Hemşirelik bölümü öğrencilerinin stresle başetme düzeyleri ile algıladıkları sosyal desteği tanımlamaya yönelik yapılan bu çalışmada, öğrencilerin aktif/etkili stresle baş etme tarzlarından KGY, IY, SDA ortanın üzerinde, pasif/etkisiz stresle baş etme tarzı olan ÇY ve BEY ortanın altında olduğu saptanmıştır. Öğrencilerin sosyal destek algıları yüksek olduğu görüldü. Doğrudan insana hizmet veren, insan sağlığ gibi önemli bir sorumluluğu yüklenen hemşirelik öğrencilerin öğrenimleri boyunca aldıkları sosyal destek ve bunu edindikleri kaynakların bilinmesi önemlidir. Hemşirelik öğrencilerinin öğrenim yaşamları süresince sosyal destek seviyelerini geliştirmeye dönük eğitim, danışmanlık ve kültürel faaliyetler, ders dişı etkinlikler düzenlenmesi vb. sosyal programların düzenlenmesi önerilebilir. Üniversite öğrenimlerinin her döneminde çeşitli stres yaratan durumlarla karşılaşabilecek öğrencilere stresle baş etme tarzları konusunda eğitim verilmeli ayrıca psikolojik danışmanlık hizmeti verilerek aktif/etkili yöntemleri kullanması sağlanabilir.

\section{Araștırmanın Sınırlılıkları}

Araştırma bir sağlık bilimleri fakültesinin hemşirelik bölümü öğrencilerini kapsadığ 1 için sonuçlar bu öğrencilerin bildirimleri ile sınırlıdır.

\section{Kaynaklar}

1- Baysan Arabacı İ, Akın Korhan E, Tokem Y, Torun R. Hemşirelik birinci sınıf öğrencilerinin ilk klinik deneyim öncesi-sırası ve sonrası anksiyete ve stres düzeyleri ve etkileyen faktörler, [Nursing students' anxiety and stress levels and contributed factors before-during and after first clinical placement] Hacettepe Üniversitesi Hemşirelik Fakültesi Dergisi [Journal of Hacettepe University Faculty of Nursing] 2015;1-16.

2- Dil S, Aykanat GB. hemşirelik öğrencilerinin öfke, umutsuzluk, stresle baş etme düzeyleri ile sosyal destek algıları arasındaki ilişkinin incelenmesi. [An examination of the relationship between anger, stress, hopelessness and perceived social support in nursing students]. Psikiyatri Hemşireliği Dergisi [Journal of Psychiatric Nursing] 2016; 7(3): 121-128 doi: 10.5505/phd.2016.49379 
3- Ekinci M, Altun Ş.Ö Can G. Hemşirelik ögrencilerinin stresle başa çıkma tarzları ve atılganlık düzeylerinin bazı değişkenler açısından incelenmesi. [Examination of the Coping Style with Stress and the Assertiveness of the Nursing Students in Terms of Some Variables] Psikiyatri Hemşireliği Dergisi [Journal of Psychiatric Nursing] 2013; 4(2):6774.

4- Yildırım N, Karaca A, Cangur S, Acıkgoz F, Akkus D. The relationship between educational stress, stress coping, self-esteem, social support, and health status among nursing students in Turkey: A structural equation modeling approach. Nurse Educ Today. 2017;48:33-39.

5- Hancioğlu Y. Üniversite öğrencilerinin algıladıkları stres düzeyleri ile stresle başa çıkma tarzları arasındaki ilişkinin incelenmesi, [The investigation of relationship between perceived stress level of university students and styles of coping with stress] Yönetim Ve Ekonomi Araştırmaları Dergisi [Journal of Management and Economics Research] 2017;15(1): 130-149.

6- Güngörmüş K, Okanlı A, Kocabeyoğlu T. Hemşirelik öğrencilerinin psikolojik dayanıklıkları ve etkileyen faktörler [Factors Influencing Resilience in Nursing Students], Psikiyatri Hemşireliği Dergisi, [Journal of Psychiatric Nursing] 2015;6(1):9-14.

7- Şahin, Buzlu, Hemşirelik Öğrencilerinde Psikolojik Sağlamlığın Öz Yeterlik Sosyal Destek Ve Etkili Baş Etme İle İlişkisinde Algılanan Stresin Aracı Rolü [The Mediating Role of Perceived Stress on Relationship of Resilience With Self Efficacy Social Support And The Effective Coping Skills in Nursing Students] Anadolu Hemşirelik Ve Sağlık Bilimleri Dergisi,[ Journal of Anatolia Nursing and Health Sciences] 2017;20:2.

8- Çapik C, Durmaz H, Öztürk M. Araştirma hemşirelik öğrencilerinin stresle başa çikma tarzlari ve etkileyen etmenler: Lefkoşe örneği. [Nursing Students' Styles of Coping with Stress and Factors That Affect Them: The Case of Nicosia] Anadolu Hemşirelik ve Sağllk Bilimleri Dergisi, 2017;20:3 208

9- Reeve KL, Shumaker CJ, Yearwood EL, Crowell NA, Riley JB. Perceived stress and social support in undergraduate nursing students' educational experiences. Nurse Educ Today. 2013;33(4):419-24.

10- Aydın A, Kahraman N, Hiçdurmaz D. Hemşirelik Öğrencilerinin Algılanan Sosyal Destek ve Psikolojik İyi Olma Düzeylerinin Belirlenmesi [Determining the Levels of Perceived Social Support and Psychological Well Being of Nursing Students], Psikiyatri Hemşireliği Dergisi [Journal of Psychiatric Nursing] 2017;8(1):40-47.

11- Wang L, Tao H, Bowers BJ, Brown R, Zhang Y. Influence of Social Support and SelfEfficacy on Resilience of Early Career Registered Nurses. West J Nurs Res.2018;40(5): 648-664.

12- Zhao F-F, Lei X-L, He W, Gu Y-H, Li D-W. The study of perceived stress, coping strategy and self-efficacy of Chinese undergraduate nursing students in clinical practice International Journal of Nursing Practice 2015; 21: 401-409.

13- Gu Y, Hu J, Hu Y, Wang J. Social supports and mental health: a cross-sectional study on the correlation of self-consistency and congruence in China. BMC Health Serv Res 2016;28;16:207.

14- Tayfur C, Ulupınar S. Sağlık Yüksekokulu Öğrencilerinin Algıladıkları Sosyal Desteğin Akademik Başarılarına Etkisi [The Effect of Perceived Social Support on Academic Achievement in Health College Students] Psikiyatri Hemşireliği Dergisi [Journal of Psychiatric Nursing] 2016;7(1):1-6.

15- Dikmen Y, Yilmaz D, Yildırım Usta Y. Hemşirelik ögrencilerinde algılanan sosyal destek ile boyun eğici davranışlar arasındaki ilişkinin incelenmesi [Examining the association between submissive behaviors and perceived social support in nursing students] European Journal of Therapeutics 2017; 23: 1218. doi: 10.5152

16- Şahin, NH. Durak, A. "Stresle başaçıkma tarzları ölçeği: üniversite öğrencileri için uyarlanması", Türk Psikoloji Dergisi, 1995;10(34): 56-73.

17- Yıldırım İ. Akademik başarının yordayıcısı olarak gündelik sıkıntılar ve sosyal destek. Hacettepe Üniversitesi Eğitim Fakültesi Dergisi 2006;30:258- 67.

18- Güler Ö, Çınar S, Hemşirelik öğrencilerinin algıladıkları stresörler ve kullandıkları başetme 
yöntemlerinin belirlenmesi [Determining to the perceived stressors and the used coping strategies of the nursing department students] Maltepe Üniversitesi Hemşirelik Bilim ve Sanatı Dergisi, Sempozyum Özel Sayıs1 2010;253-261.

19- Ergin A, Uzun SU, Bozkurt Aİ. Tıp fakültesi öğrencilerinde stresle başa çıkma yöntemleri ve bu yöntemlerin sosyodemografik özelliklerle ilişkisi [The methods of coping with the stres among medical faculty students and the relationship between sociodemograhic characteristics and these methods], Firat Tip Dergisi,[Firat Med J] 2014;19(1):31-37

20- Subhi Al-Zayyat A, Al-Gamal E. Perceived stress and coping strategies among Jordanian nursing students during clinical practice in psychiatric/mental health courses International Journal of Mental Health Nursing 2014; 23, 326-335.

21- Hamaideh SH, Al-Omari H,Al-Modallal H. Nursing students' perceived stress and coping behaviors in clinical training in Saudi Arabia, Journal of Mental Health, 2017;26:3, 197-203.

22- Chan C, So WKW, Fong DYT. Hong Kong baccalaureate nursing students' stress and their coping strategies in clinical practice. Journal of Professional Nursing, 2009; 25:5, 307-313.

23-Temel E, Bahar A, Çuhadar D. Öğrenci hemşirelerin stresle baş etme tarzları ve depresyon düzeylerinin belirlenmesi. Determination of Coping Attitude with Stress and Depression Level of Nursing Students Firat Sağlık Hizmetleri Dergisi, 2007;2(5), 107-118.

24- Y1lmazel G. Sağlık yüksekokulu ögrencilerinde algilanan sosyal destek ve sağlıkla ilişkili davranışlar. [Perceived Social Support and Health Related Behaviors at the School of Health Students] New/Yeni Symposium Journal 2013; 51: 3. 